\title{
Presentation and Analysis on the Different Cultural Interpretations: Examining Chinese and Japanese Textbooks and Museums
}

\author{
Zhuolin Li \\ Linden Hall School, Lititz, PA, USA \\ Email: zli1218@outlook.com
}

How to cite this paper: Li, Z. L. (2018). Presentation and Analysis on the Different Cultural Interpretations: Examining Chinese and Japanese Textbooks and $\mathrm{Mu}-$ seums. Advances in Historical Studies, 7, 31-57.

https://doi.org/10.4236/ahs.2018.72004

Received: February 19, 2018

Accepted: May 29, 2018

Published: June 1, 2018

Copyright $\odot 2018$ by author and Scientific Research Publishing Inc. This work is licensed under the Creative Commons Attribution International License (CC BY 4.0).

http://creativecommons.org/licenses/by/4.0/

\begin{abstract}
The paper, presenting the distinctions between Chinese and Japanese textbooks and museums' descriptions on Second Sino-Japanese War, tends to offer explanations for the different presentations of the war. Textbooks from high school mandatory world history courses from Ikeda Senior High School attached to Osaka Koku University in Osaka, Japan and ChenJingLun High School in Beijing, China are chosen to compare. For war-relating museums, the Unit 731 Museum in Harbin, China and the Peace Memorial Museums of Hiroshima, Japan are both one of the most important and profound war museums in both nations. Chinese textbook straightforwardly points out Japanese territorial expansion, Japanese brutal atrocities, and the successful achievement CPC made in the war. However, the Japanese textbook describes Japan's domestic economic crisis during WWII, Chinese Civil War between the CPC and Kuomintang, and Japanese diplomacy. For the museums, the Hiroshima Peace Memorial Hall's Main Building tells tragedies caused by the A-bomb, survivors' emotional stories, and the huge mental and physical damage to the civilian population. The Unit 731 Museum's Bacteriological Exhibit Hall reveals the human experiments in the secluded Unit 731 military base. Assuming the government-approved mandatory history textbooks in both nations convey the historical information preferred by current national government, and museums serve as the repository of abundant documents and visual evidences, the paper further analyzes the distinctions from social, historical, and political aspects; national war memories, Japanese sense of excluded national pride, postwar US-Japanese relation, and government legitimacy are factors examined to be accounted for the notable distinctions between Chinese and Japanese textbooks and museums' descriptions of the war.
\end{abstract}

\section{Keywords}

Second Sino-Japanese War, Japan History Textbook Controversy, War 


\section{Introduction and Background}

Under the influence of Western imperialism and the emergence of militarism, Japan launched the Second Sino-Japanese War in 1937. After eight years of protracted warfare, the "A-bombs"1 dropped in Hiroshima and Nagasaki succumb Japan, and the emperor announced the unconditional surrender. Decades after the Great War, controversies still exist; especially on the cultural aspect, the interpretation of the war still creates tensions between China and Japan.

This paper tends to present and compare Chinese and Japanese textbooks and museums, and tries to offer explanation for the differences between these Chinese and Japanese cultural reflection of the war from social, historical, and political aspects. Considering the accessibility of the evidences, this paper compares textbooks from high school mandatory world history courses from Ikeda Senior High School attached to Osaka Koku University in Osaka, Japan and ChenJingLun High School in Beijing, China. For war-relating museums, Unit 731 Museum in Harbin, China and the Peace Memorial Museums of Hiroshima, Japan are chosen.

This paper assumes history textbooks as strong evidence revealing a nation's politically preferred historical information. Whether in China or Japan, views represented in the textbooks, used in mandatory history courses, are authorized by the government. In China, the single-party system and the strong Communist Party influence imposed within the nation result in scarce controversies on the textbook issues. However, the situation is difference in Japan with when describing World War II, Japanese historical textbooks, been accused of evading important historical facts regarding brutal invasions, were criticized by other Asian countries; the internationally controversial textbook issue has also aroused complex domestic debates between the conservatives and the progressives. The conservatives blamed the progressive as "trying to use public education to mold students into leftist cosmopolitans who feel no affection foSr their country, traditions or history". On the other hand, the progressive has considered the conservatives "wishing to make the students reactionary chauvinists oblivious of Japan's modern history of oppression" (Shibuichi, 2008). China and Korea, playing a paramount foreign role in this debate, "are concerned with how Japanese imperialism and invasions are depicted in Japanese textbooks" (Shibuichi, 2008). This long-term struggle began in 1947, when the Japanese government established a textbook authorization system that screened drafts of textbooks. Coming into the twenty-first century, the most prominent conservative leader on this textbook controversy is Fujioka Nobukatsu, a professor of Tokyo University,

${ }^{1}$ Abbreviation for "atom bomb", which is the nuclear weapon that uses nuclear fission as its source of energy. 
known for his determination for removal of Japanese wartime atrocities in WWII from history textbooks.

Museums are chosen as evidence of this paper due to the great amount of articles and documents they exhibit; museums often reflect and mold citizens' impressive memories and deep emotions of the war. The particular Unit $731 \mathrm{mu}$ seum in Harbin, China and the Hiroshima Peace Memorial Museums are chosen because of their common characteristic: the enormous damage on civilian population. Unit 731 is a secret biomedical military troop that explored biochemical warfare by proceeding humans' bodies experiments; the museum, which situated besides the actual military base of the Unit 731 in Harbin, reveals the inhumane tragedy that cause indelible harm on ordinary Chinese people. Founded in 1955, the Hiroshima Peace Memorial Museum portrays the unprecedented catastrophe caused by that single destructive bomb; Japanese witnesses' stories, survivor's testimony, and numerous evidences are displayed. As a "peace" museum, in contrast to those "war" museums that ignore the pain Japanese inflicted on other nations and made incessant emphasis on victimization, Hiroshima Peace Memorial Museum made slight effort to acknowledge Japan's wartime cruelties and make Japan both the victimizer and the victim (Jeans, 2005). In contrast to the government-sponsored Unit 731 Museum, Hiroshima Peace Museum belongs to an organization called Japanese Network of Museums for Peace. Described by Roger B. Jeans, this network “is antinuclear, idealistic about 'peace', does not care for the US-Japanese alliance, and probably could be described as left-wing" (Jeans, 2005).

\section{Presentation on the Different Cultural Interpretations: Evidence 1 (High School Mandatory World History Courses from Ikeda Senior High School Attached to Osaka Koku University in Osaka, Japan and ChenJingLun High School in Beijing, China)}

This paper extracts the description of Sino-Japanese War from the selected Chinese and Japanese textbooks. In order to present a clear comparison, the Japanese textbook's description is marked with blue color, and the Chinese textbook's description is marked with red color. The comments the paper makes are marked in black color.

\subsection{Japanese Textbook Depicts the Severe Domestic Economic Crisis in Japan, Offers a Reason for Developing Economic Zone in China}

The Great Depression had a devastating impact on the Japanese economy as well [as the economies of other advanced nations]. The unemployment rate increased, and the farming villages in northeastern Japan and other regions suffered (People's Education Publishing House and Course Material Institute History Research and Development Center, 2007). 


\subsection{Chinese and Japanese Descriptions on the Manchurian Incident}

After Japan had occupied Taiwan, they had craved for Chinese territory. Since the Manchurian Incident in 1931, Japan created a series of Chinese invasion; the Northeast part of China had fallen; the Huaber area was gradually getting colonized; the national crisis was getting severe (Kazuhiko, 2017).

The Japanese government promoted cooperative diplomacy and laissez-faire capitalism as a counterweight to the military-faction officials who hoped to expand and preserve Japan's economic zone in China. In this context, the government signed the London Naval Agreement.

However, as the sense of crisis deepened, the Japanese military caused the Manchurian Incident in 1931, and the government in 1932 turned away from internationalism and created the country of Manchukuo. The League of Nations criticized Japan's attitude, and in 1933 Japan withdrew from the League of $\mathrm{Na}$ tions. Domestically, popular opinion increasingly supported the coercive plans of the military to convert the "Manchuria Zone" (Manchuria and the occupied parts of Mongolia) into Japan's lifeline, to be developed for the sake of the heartland [i.e., the Japanese home islands]. This also was a period when many Japanese political figures were assassinated. The winds opposing democracy gradually were becoming stronger (People's Education Publishing House and Course Material Institute History Research and Development Center, 2007).

In Japanese texts, the military, as distinct from the civilian government, is seen as initiating actions. In Chinese texts, however, the Japan as a single entity is to blame. On the other hand, while the Chinese history textbook asserts Japan started "territorial invasion", Japan claims their actions as "preserving economic zone" in China. While Chinese history textbook continuously uses words like "invasion", "colonized", and "national crisis", the Japanese textbook uses many vague phrases such as "cause the Manchurian Incident", "created the country of Manchukuo".

\subsection{Chinese and Japanese Descriptions on the Marco Polo Bridge Incident}

On the night of July $7^{\text {th }}$ of 1937, the Japanese soldiers used a solder's missing as an excuse, and demanded to search for the soldier in Waping town ${ }^{3}$. Their request was refused by Chinese soldiers. However, Japanese soldiers invaded the Waping town and the Marco Polo Bridge; and the Chinese soldiers devote into resistance. The Marco Polo Bridge Incident marked the beginning national Anti-Japanese War. Later Japan dispatched a hundred thousand soldiers to invade China; Beijing, Tianjing had successively fallen (People's Education Publishing House and Course Material Institute History Research and Development Center, 2007).

${ }^{2} \mathrm{HuaBei}$ area is a geological region of northern China, including Beijing, Tianjin City, Hebei Province, and Shanxi Province.

${ }^{3}$ Wanping town is situated in southwest of Beijing, near the Marco Polo Bridge. 
In July 1937, the Marco Polo Bridge Incident took place, and Japan entered into a period of warfare with China. Gradually, the scale of fighting expanded and developed into all-out war (the Japanese-Chinese War) (Kazuhiko, 2017).

While the Chinese textbook elaborates on how Japan invade into Wanping City, which started the "Anti-Japanese War", Japanese textbook vaguely says "the Marco Polo Bridge Incident took place" and started the "the Japanese-Chinese War”.

\subsection{Chinese and Japanese Descriptions on CPC and Kuomintang Party}

Facing the threat of Japanese full-scale invasion to China, the Communist party and the Kuomintang party had stopped the civil war, forming the united force to resist against the Japanese. In August, 1937, CPC had decided to unit all power of the nation, to gain victory through civilians joining the war. Afterwards, the Eight Route Army and the New Fourth Army went behind the enemy, widely carrying out the independent guerilla warfare, establishing the Anti-Japanese military base (People's Education Publishing House and Course Material Institute History Research and Development Center, 2007).

In China, following the Manchurian Incident anti-Japan protests became stronger and stronger, and the civil war between the Kuomintang and Communists continued. The Communist army of Zuikin ${ }^{5}$ [瑞金] advanced into Sichuang ${ }^{6}$ [四川省] and Kanshukusho ${ }^{7}$ [甘肃看], reorganized matters there, and then made Enan ${ }^{8}$ [延安] into its base (this is the so-called Chösel [ The Long March, 長征], 1934-1936). The Communist Party, which was built upon the leadership of Mo Tse-tung, entered into what is called a "United Front" with the Kuomintang, and the Seian [西安] Incident ${ }^{10}$ occurred at the end of 1936 (Kazuhiko, 2017).

Both the Chinese and Japanese history textbooks mention the domestic Communist Party and the Kuomintang in China. The Chinese textbook explains the one of the great contributions of CPC, which is uniting the whole nation against Japanese invasion. And Japanese textbook mostly descripts the civil war between CPC and Kuomintang; the Long March, which is a major conflict between the CPC and Kuomintang, is elaborated in the Japanese textbook. The Japanese text makes China looks "chaotic" and divided against itself, thus implicitly justifying Japanese intervention.

\footnotetext{
${ }^{4}$ The Chinese calling of the Sino-Japanese War.

${ }^{5}$ Ruijin is a famous city in JiangXi province of China. As the beginning of the Communist Long March, Ruijin is also called the cradle of CPC.

${ }^{6}$ Sichuang is a province in southwest China.

${ }^{7}$ Kanshukushō is a province in northwest China. Kanshukushō borders Sichuang.

${ }^{8}$ Enan is a city in Shanxi province of China.

${ }^{9}$ Chōsei, the Long March, is a military retreat of the Red Army of the CPC; throughout the retreating process, series of battle have been fought.

${ }^{10}$ Seian Incident is when Chiang Kai-Shek, the leader of Kuomintang, was detained for the purpose of disregarding the civil war with the Communist Party, and uniting the Kuomintang and the Communist Party to fight against Japanese invasion.
} 


\subsection{Chinese and Japanese Descriptions on Invasion of Nanjing}

The Japanese invaders burned, killed, raped women, and ransacked wherever they went, no deeds were too evil to do. After Japanese military had captured Nanjing on December, 1937, the peaceful Nanjing civilians went through extremely inhumane massacre under the Japanese. Within six weeks, more than three hundred thousand harmless civilians and soldiers that had put down their weapons had been brutally slaughtered; some were shot; some were stabbed; some were buried alive, some were burned alive... the massacre was extremely cruel (People's Education Publishing House and Course Material Institute History Research and Development Center, 2007).

During 1937, the Japanese Army occupied major cities, such as Kahoku area ${ }^{11}$ [ 華北], Shanghai and Nanjing (Kazuhiko, 2017).

Chinese textbook elaborate on Japanese "extremely inhumane massacre" in Nanjing; the only time the city Nanjing is mentioned in Japanese textbooks is the list of occupied cities.

\subsection{Japanese Textbook Descriptions on Kuomintang and Japanese Diplomacy}

Then, in September, the Kuomintang formally established the Second Kuomintang-Communist Front. The Kuomintang transferred its headquarter and continued its resistance to Japan. The war expanded beyond Japan's expectations. Japan was becoming increasing independent diplomatically and, under the guidance of the Army, shifted to a new kind of diplomacy. That resulted in a set of mutual-cooperation and mutual-defense alliances with Germany and Italy (1937). In this way, Japan's relations with Great Britain and the United States worsened. Japan elected to take a neutral stance with the Soviet Union (Kazuhiko, 2017).

\subsection{Chinese Textbook Description on Japanese Atrocities, Including the Tragedy in PanJiaYu and the Unit 731 Bacterial Warfare}

A morning on the beginning of 1941, a Japan's puppet troop has surrounded PanJiaY ${ }^{12}$ (潘家峪), FuRun county (丰润县), HeBei province (河北省), and chased the civilians of the whole village into a huge pit on the west of the village. The troop compelled the civilians to give the location of the Eight Route Army. Even when their lives were threatened, the civilians did not succumb and refuse to give the location. The frantic Japanese used machine guns and grenades to brutally massacre the civilians. Among one thousand and five hundred people of the village, a thousand two hundred were killed in this tragedy.

\footnotetext{
${ }^{11}$ Kahoku area is the Japanese calling of the Huabei area, which is a geological region of northern China; Kahoku area includes Beijing, Tianjin City, Hebei Province, and Shanxi Province.

${ }^{12} \mathrm{PanjiaYu}$ is a village in HeBei province. After the Marco Polo Bridge incident, the Eight Route Army instigated the civilian population, and established extensive anti-Japanese bases. PanJiaYu is one of the famous anti-Japanese fortress village.
} 
The cruel Japanese invaders established the troop, which focused on exploring bacterial warfare, called Unit 731. They inhumanly used alive Chinese in experiments. More than three thousand Chinese were killed because of the experiments (People's Education Publishing House and Course Material Institute History Research and Development Center, 2007).

Chinese textbook elaborates and emphasizes on the "brutal massacre and bacterial warfare", and the damage on civilian population. But Japanese textbook has not included this part.

\subsection{Chinese Textbook Description on the Victory, Contribution of the Communist Party, and the Foreign Battlefields Chinese Soldiers Have Involved in}

The second half of the year 1940, Peng Dehuai ${ }^{13}$ (彭德怀) directed more than a hundred legions of the Eight Route Army. Along the two thousand kilometers front of Huabei area, unplugged more than three thousand enemy's bases. The Hundred Regiments War was a large-scale battle that Chinese army took the initiative to attack on the Japanese. The China Communist Party led soldiers and civilian in the anti-Japanese bases, carried out extensive guerilla warfare, resisted more than half of the Japanese invaders, and became the mainstay of the War of Resistance against Japan.

Not only fighting domestically, our nation's army had also developed foreign battlefield. At the beginning of 1942, the Japanese went north from Thailand and Myanmar, trying to attack YunNan province of China. In order to protect the Burma Road, an international transportation line, the Chinese government dispatched expeditionary forces to Myanmar fighting against the Japanese. A British troop was trapped in Myanmar by the Japanese, after fierce fighting, the Chinese expeditionary force had rescued the more than seven thousand trapped British soldiers. In the beginning of 1945, under the corporation of British and American army, Chinese expeditionary troop defeated the Japanese invading Myanmar (People's Education Publishing House and Course Material Institute History Research and Development Center, 2007).

The Chinese textbook has once again specified the success CPC achieved in the Anti-Japanese War; important general and famous battles are mentioned. And Chinese extending to foreign battlefield to defeat Japanese forces.

\section{Presentation on the Different Cultural Interpretations: Evidence 2 (Hiroshima Peace Memorial Hall and Unit 731 Museum)}

The Hiroshima Memorial Museum is composed by the Main Building and East Building. Currently (July of 2017), the Main Building is closed for renovation; thus for specific evidences, this paper looks at the displays, including war-damaged articles, survivors' testimonies, and humans' bodies damage by

${ }^{13}$ Peng Dehuai is a respected military leader of the Chinese Communist Party. He is one of the outstanding leaders of CPC, the People's Republic of China, and the Chinese People's Liberation Army. 
radiation, etc., on the previous website depicting exhibits prior to the renovation. The order of display in the Main Building is depicted by Figure 1; following the suggested tour path, the separate sections are "8:15 a.m., August 6, 1945", "Damage by Heat Rays", "Damage by Blast”, “The Fury of the Conflagration”, "Damage by the Radiation", "Relief and Rescue Activities", "A-bomb Drawings by Survivors", "Recorded Testimony of the Atomic Bomb Survivors", and "Message of Peace". One or two powerful representative exhibited articles are chosen from several sections.

\subsection{8:15 a.m., August 6, 1945}

On the Figure 2 is a lunchbox that suffered from the explosion six-hundred

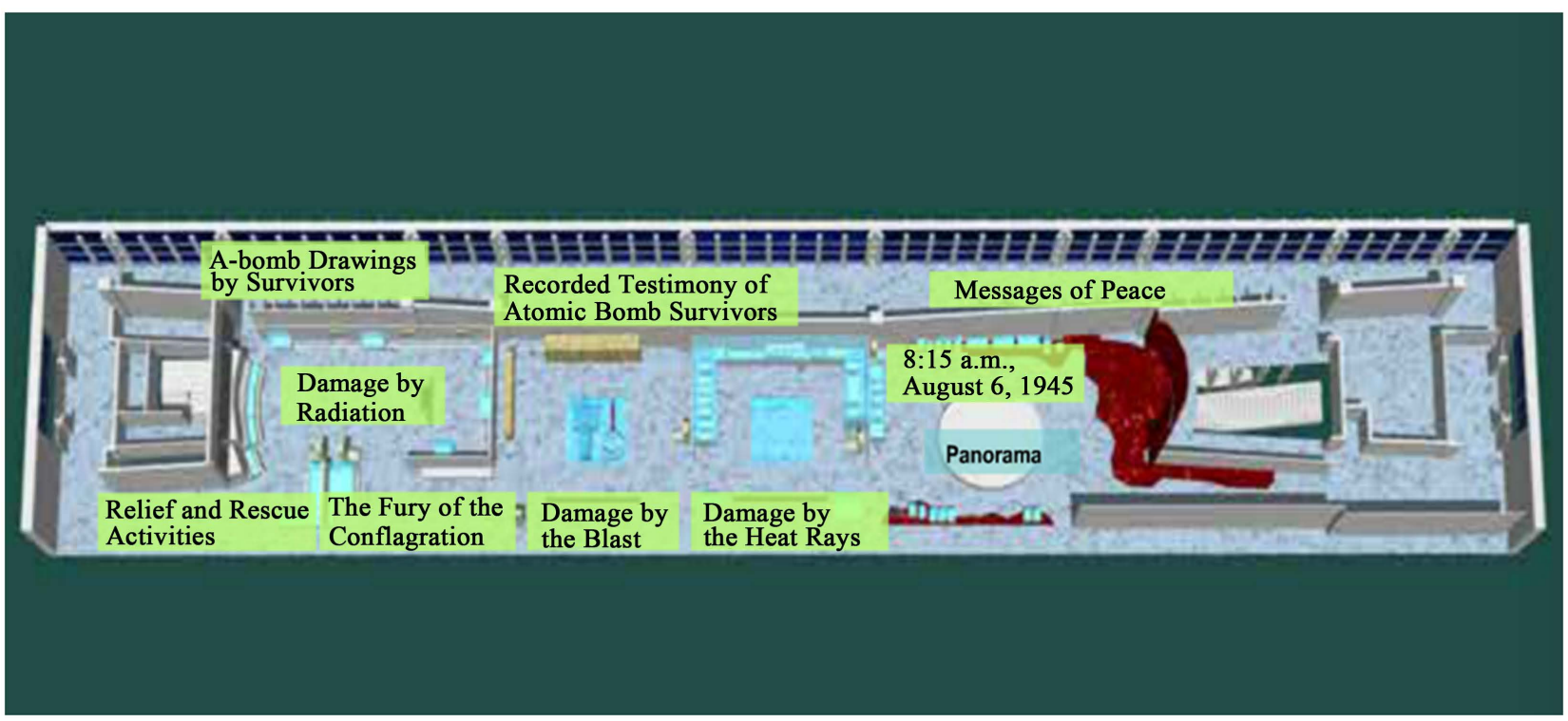

Figure 1. "Map of the Main Building”, Hiroshima Peace Memorial Hall, 2013.

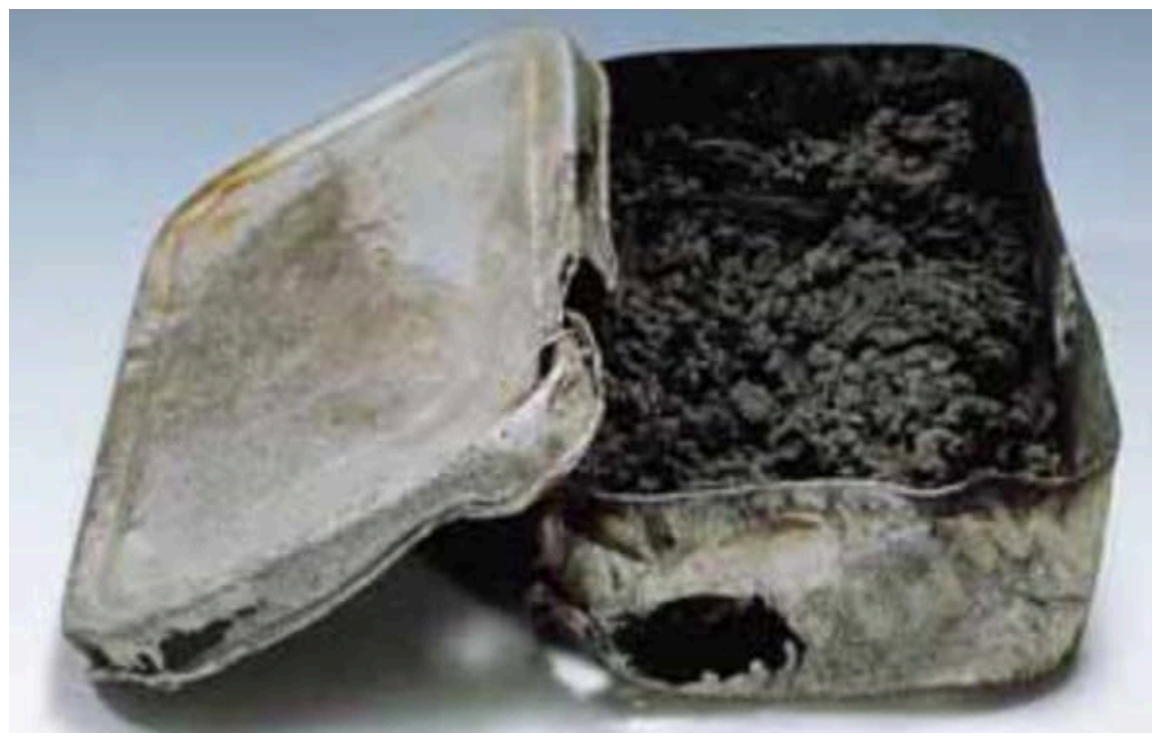

Figure 2. "The Lunchbox", Hiroshima Peace Memorial Hall, 2013. 
meters away from the hypocenter. According to the official website of Hiroshima Peace Memorial Hall, this lunch box was owned by Shigeru Orimen, a first-year student (in 1945) who attended the Second Hiroshima Prefectural Junior High School. "He was exposed to the bomb at his building demolition work site at Nakajima-Shin-machi". His mother searched everywhere for him but eventually found a body clutched with this lunch box. Shigeru, whose father and brother went to the front to fight the war, worked hard in the field. "He plowed the fields and cultivated gardens on the mountains and in the bamboo grove". The lunch box contained the first harvest of the year, and Shigeru was extremely happy about it. His mother went desperately sad when she realized that and her son had never got a chance to eat it.

\subsection{Damage by Heat Rays, Damage by Blast, the Fury of the Conflagration}

This piece of air-raid hood (Figure 3) was found 1700 meters from the hypocenter. "Kuyusaku Oda was exposed to the bomb in front of the main gate of the Hiroshima Railway Hospital in Osuga-cho. The back of the student's uniform was burned away. The air-raid hood ties to his shoulder was also burned".

This fused lump of small glass bottles (Figure 4) was found 1800 meters away from the hypocenter. Tadashi Fujitsuka was a four-year old boy, and he was exposed and burned over his body. He immediately died on the nest day. When his nineteen-year old brother Minoru returned from the military a month later. He felt great grief over Tadashi's death and the crushed Fujitsuka house. Later this lump of glass bottles was dug out from the ruins; the bottles were melted into lump by the extremely high temperature. "When he saw it, Munoru mumbled, 'Must have been really hot'”.

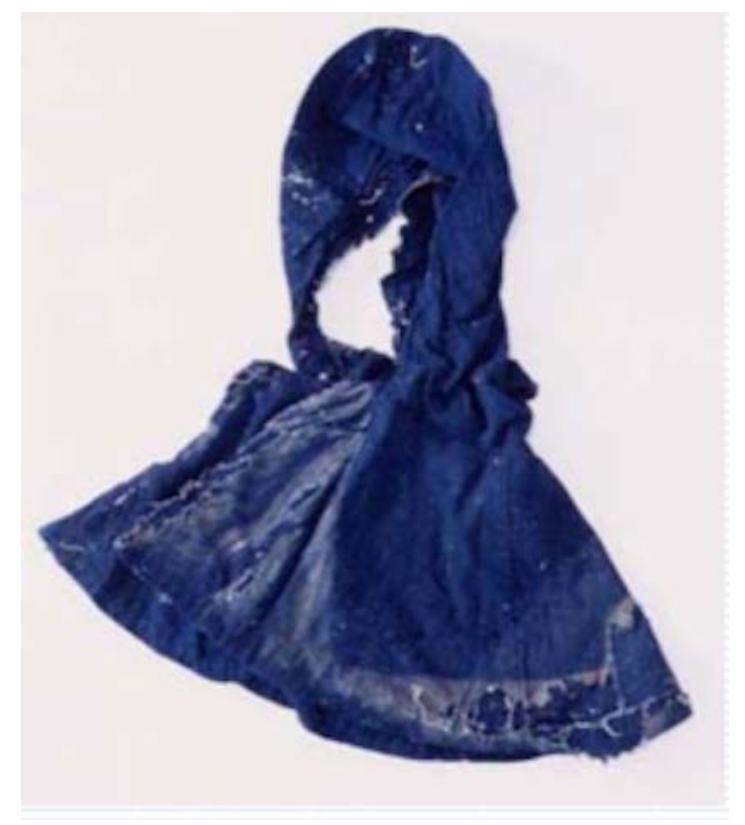

Figure 3. "The Air-Raid Hood”, Hiroshima Peace Memorial Hall, 2013. 


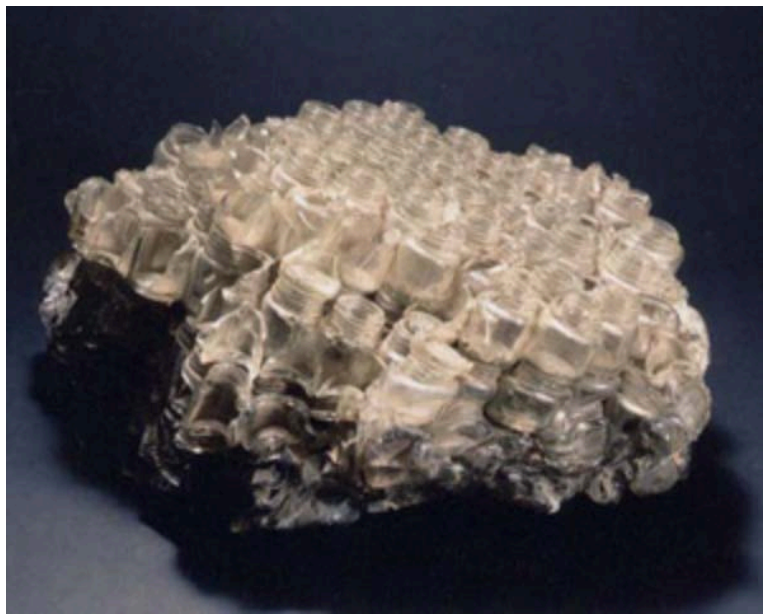

Figure 4. "The Fused Lump of Small Glass Bottles", Hiroshima Peace Memorial Hall, 2013.

\subsection{Damage by the Radiation}

After the explosion took place, the dust, debris, and root were brought high into the air by a giant mushroom cloud. These dust and root became radioactive and mixed with the water vapor. The rain which carries these toxic matters falling back on earth is called the "black rain". "Fish died and floated to the surface in the ponds and rivers where this rain fell. Many of the people who drank from wells in areas where the black rain fell suffered from diarrhea for three months". Figure 5 shows some desperate survivors drinking the harmful rainfall, while some people are already suffering from the radioactive water.

The word "keloids" refers to the abnormal scars left by skin regeneration growing excessively. Keloids appeared frequently in 1946 to 1947 . "Fifty to sixty percent of those burned directly by the A-bomb heat rays within about two kilometers from the hypocenter developed keloid scars". Figure 6 is a woman who suffered from keloids not only on her back and arms, but also her face and joint of her legs. The keloids cause great physical and mental pain when she tries to move her joint.

This part of bone marrow (Figure 7) was donated by the Hiroshima Red Cross and Atomic-bomb Survivors Hospital. A nine-year old girl experienced no injuries or burns when she was exposed in a wooden house. In June, 1959, decade after her healthy and strong growing, she felt fatigue, bleeding, and other illness. These symptoms continued and she went to the hospital. However, "In late June the following year, her legs began swelling without subsiding, eventually to the point of bleeding. She died in late July".

\subsection{Relief and Rescue Activities}

In the Figure 8 and Figure 9, most hospitals and medical institutions in Hiroshima were destroyed. Shown in Figure 8, similar kinds of emergency relief station were built whenever the injured gathered. "The number of stations increased from the day of the bombing until the 9 th, peaking at 53. Beginning on 


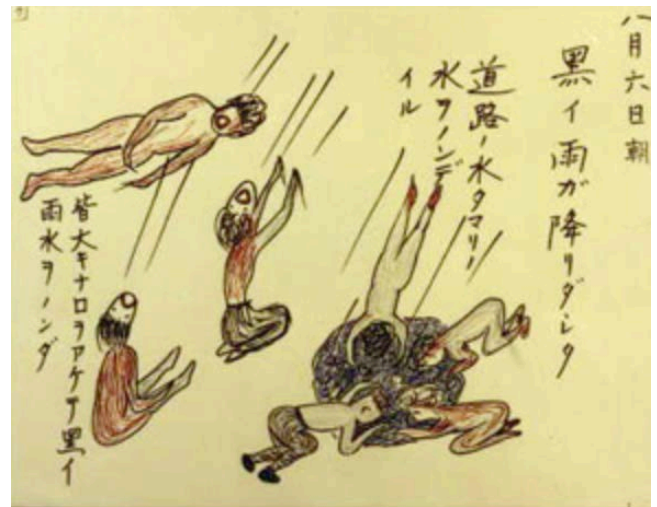

People Drinking Black Rain

Drawn by Tomiko Miyaji

Figure 5. "People drinking Black Rain”, Hiroshima Peace Memorial Hall, 2013.

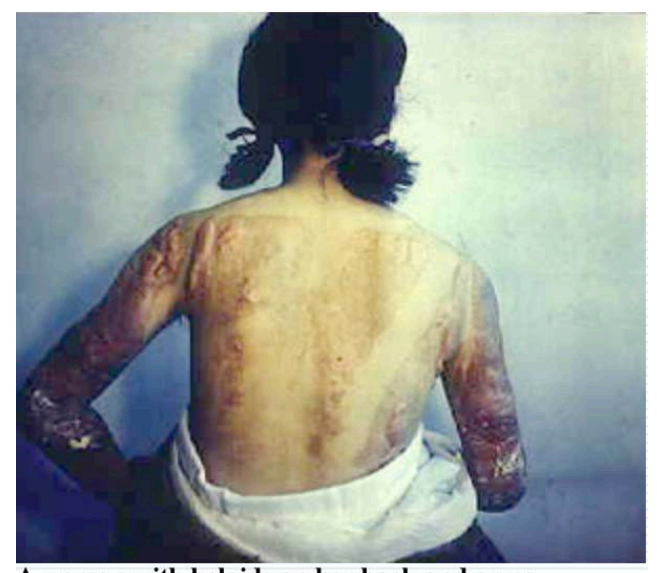

A woman with keloids on her back and arms

November 13, 1945, Photo by US Army

Figure 6. "A Woman with Keloids on Her Back and Arms", Hiroshima Peace Memorial Hall, 2013.

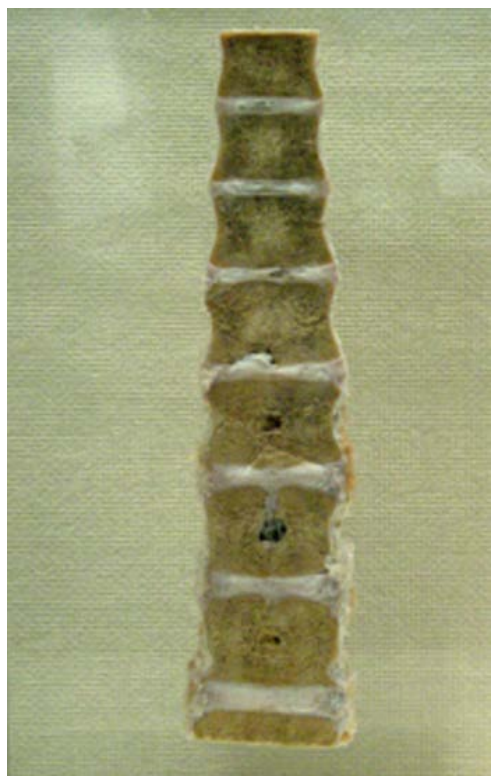

Figure 7. “The Bone Marrow”, Hiroshima Peace Memorial Hall, 2013. 


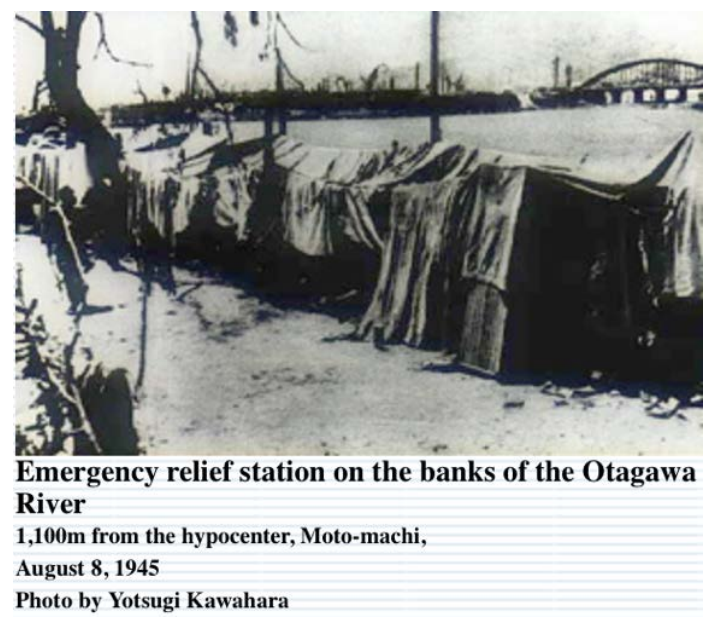

Figure 8. "Emergency Relief Station on the banks of the Otagawa River", Hiroshima Peace Memorial Hall, 2013.

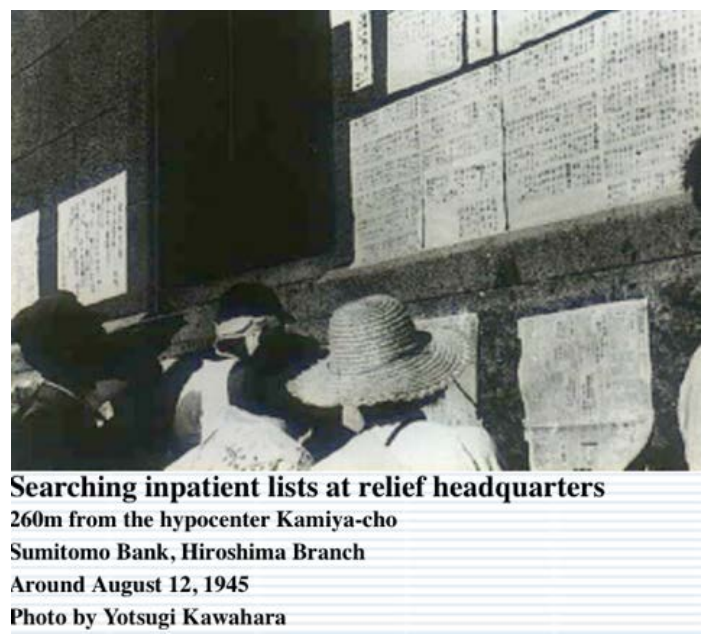

Figure 9. "Searching In Patient Lists at Relief Headquarters", Hiroshima Peace Memorial Hall, 2013.

the 11th, relief stations began closing, but by October 5, the total number of injured admitted to such stations stood at 105,861. Outpatient services were provided to a cumulative total of 210,048 people". Once the news of the A-bomb explosion became pervasive across the nation. Many Japanese traveled to Hiroshima to look for their family and friends. They patiently searched from one emergency relief station to another, but they never even found the bodies of people. "Many families never received any ashes or personal belongings".

\subsection{A-Bomb Drawings by Survivors}

A group of heavily injured people escaping to the suburban areas from Figure 10.

For the Figure 11, "as I fearfully crossed the railroad bridge, I saw red, blue, green, and purple corpses swollen three or four times floating under it". Toshiko Kihara Age 17 at time of bombing, 47 at time of drawing. 


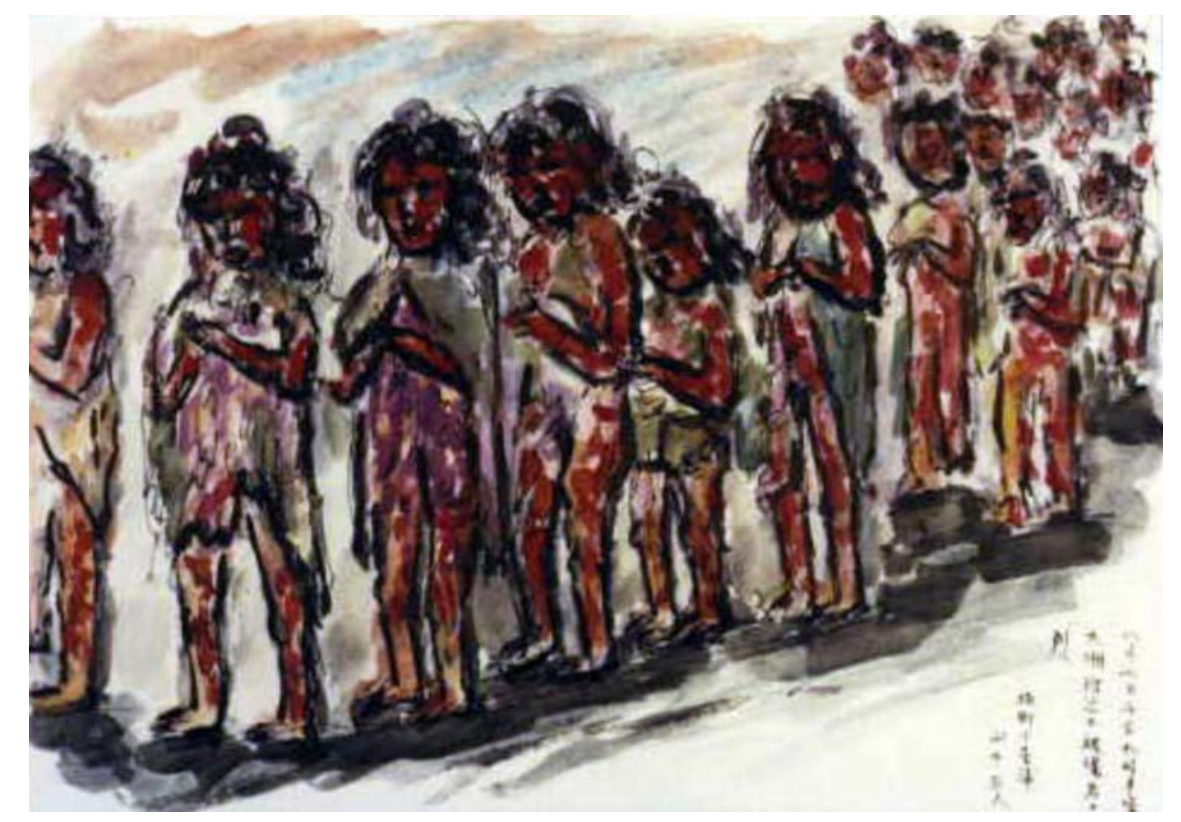

Figure 10. A group of heavily injured people escaping to the suburban areas.

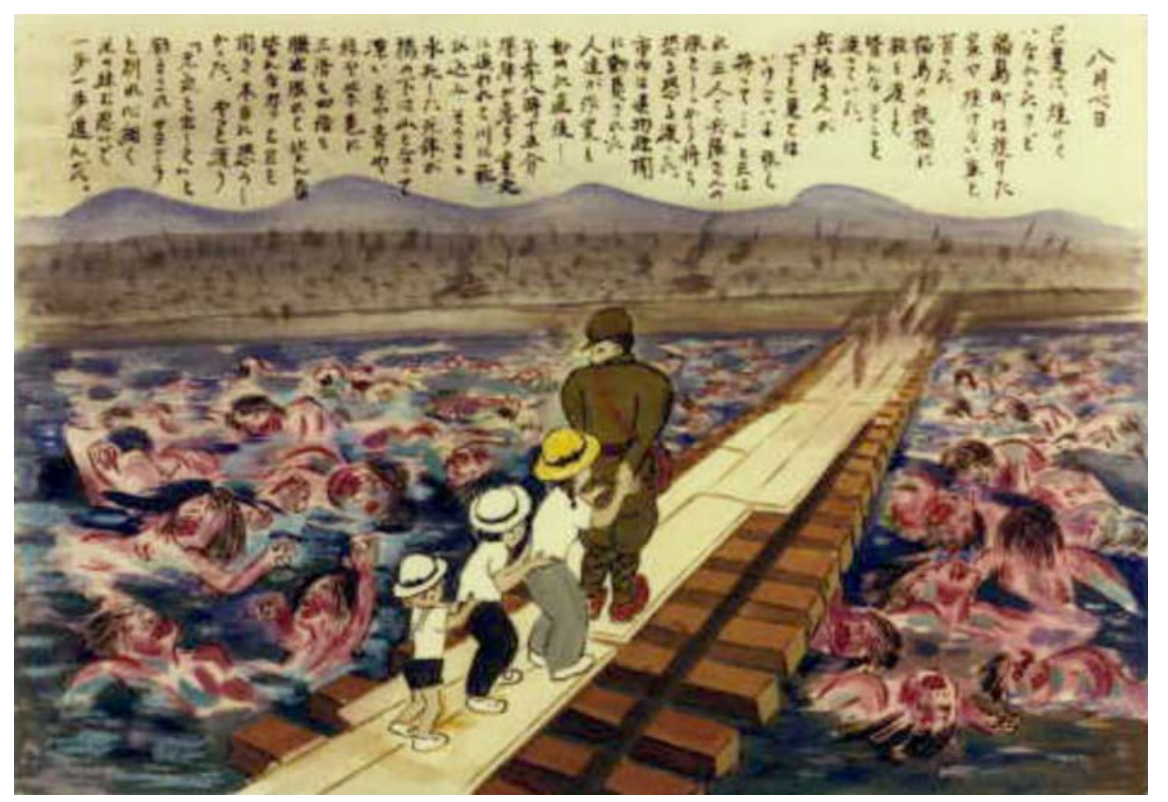

Figure 11. Toshiko Kihara Age 17 at time of bombing, 47 at time of drawing.

For the Figure 12, "while searching for my daughter, I came across a mountain of corpses in a street of carnage. People had evidently rushed to plunge their faces in the water of a cistern, where they died with their arms around each other, clinging to the side. How they must have screamed for water. My heart aches for them. I clasp my hands in prayer". Kekune Komatsu (37 at the time of the bombing, 67 when she drew this picture).

\subsection{Recorded Testimony of the Atomic Bomb Survivors}

"Conveying the A-bomb Experience" by Suzuko Numata. 


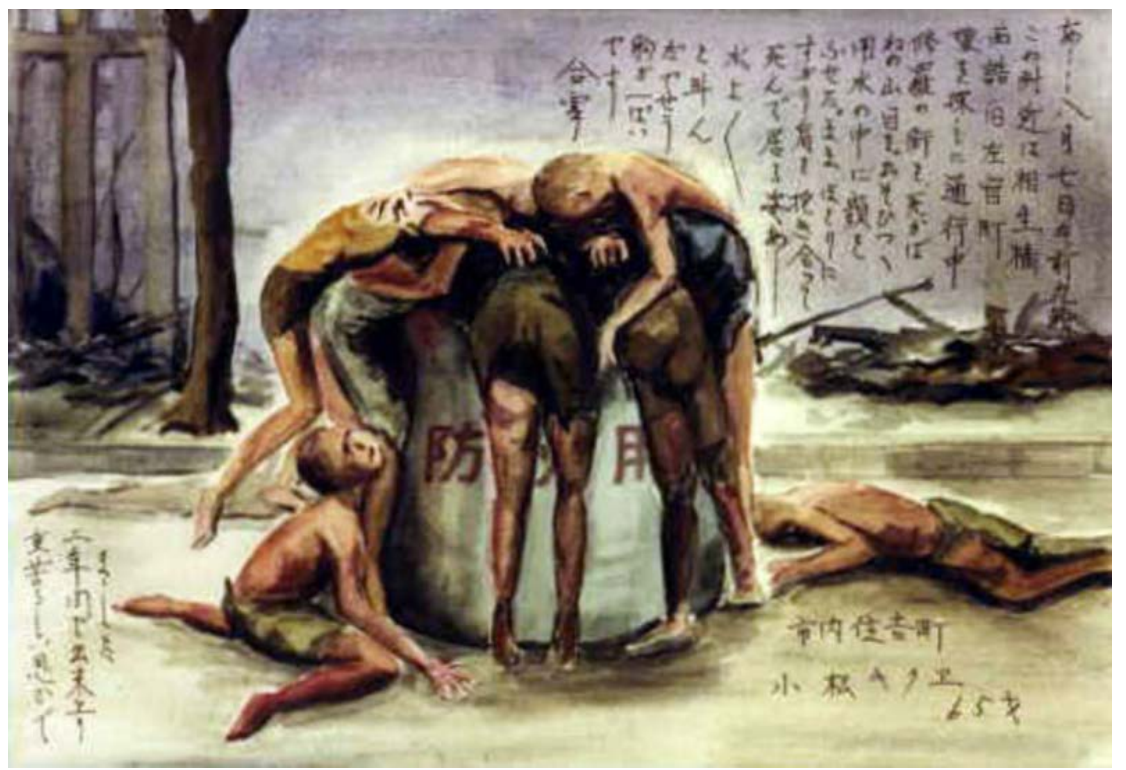

Figure 12. Corpuses of people trying to jump into the fire-fighting cistern.

"During the so-called Fifteen-year War from the Manchurian Incident to the surrender of Japan on August 15, 1945, we were never told what Japan was doing as an aggressor nation. We never heard about our invasions of China and Southeast Asia, the Nanking Massacre, the bombing of Chongquing, or the terrible suffering we inflicted in Korea. Unpleasant facts about the war were kept from us... I didn't know it then, of course, but later learned that I had seen the flash released at the moment the atomic bomb exploded... Although I lost consciousness several times, when they got the bleeding stopped, I regained consciousness and my life was saved. When my sight and hearing became clearer, I saw figures that hardly appeared human, and the cries and screams they uttered in their death agony-“Water!", "Help!”, “Mother!”-were from a living hell.

Someone with a blackened face crouched in pain at my right foot. It was my younger sister, bleeding from the many glass fragments sticking into her head and arms. I knew who she was only because she called me, "Sister!" How long had it been since I saw that beautiful flash? The sky suddenly turned black and big drops of rain began to fall. Later I heard that it was radioactive black rain. The rain soaked everything-the stump of my leg, the burn victims, and the dead. Oddly, my left ankle didn't hurt me at all, but after three days without medical treatment, the wound festered up to my knee, endangering my life... Our family was not completely reunited until after the 15th of August when my younger brother was released from military service and returned home. I had been scheduled to marry in August, but my fiancé had been killed in July. I learned of his death in late-August at the height of my suffering from the pain and anguish of losing a leg. I took the news as if it were happening to someone else. I lost all desire to live, or even to think, and was unable to appreciate the fact that I had been saved when countless precious lives had been lost. Instead, all my sorrow turned to hatred, and my days were filled with thoughts of suicide". 


\subsection{Message of Peace}

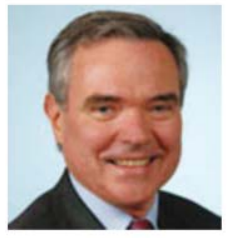

\section{Bernard Accoyer}

President of the French National

Assembly

Participant in the Seventh G8 Speakers' Meeting

September 2, 2008

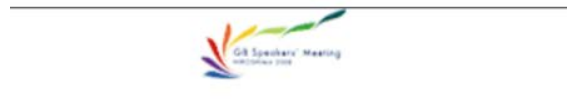

Here in Hiroshima, a city more full of death than any other, after so many conflicts in the

Ici à thisobleima, ville meentic phes pue tont anta, opis tont o corfiti effwyaths stam l'histaive Sn monse, il fout mon sumener

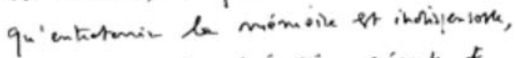
pon sclaiver le givination pients $t$

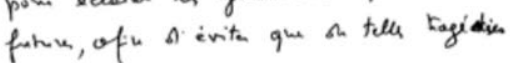
me se veprosmisent. history of the world, we must remember that the memory must be kept alive, to enlighten present and future generations so that such tragedies will never again be repeated.

It is in peace that humanity grows.

(Signature)

September 2, 2008

$$
\begin{aligned}
& \text { C'est rom la poix w } \\
& \text { t hument' me grounst. }
\end{aligned}
$$

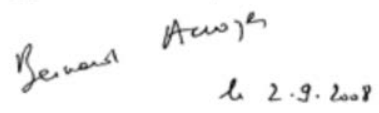

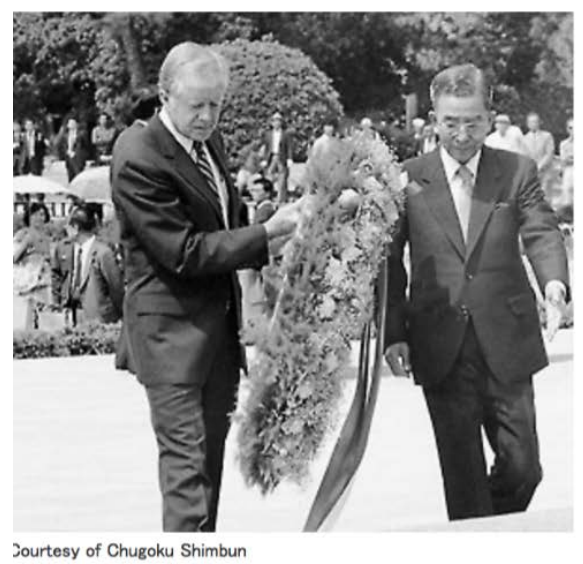

\section{Jimmy Carter}

Former President of the United States of America

Nobel Peace Prize 2002 Laureate

May 25, 1984

Jourtesy of Chugoku Shimbun

This memorial must be a constant and

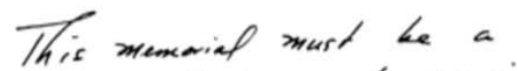
permanent reminder for all people to work for
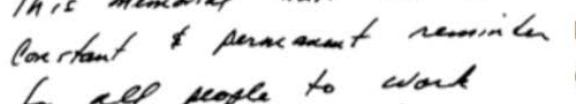

for cep peotle to wort

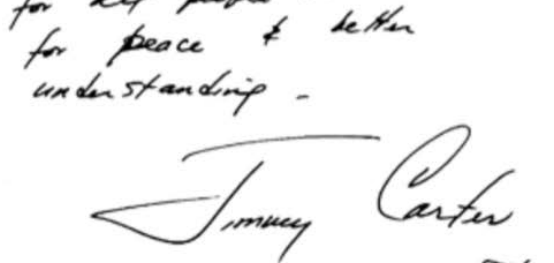

peace and better understanding.

(Signature)

5.25 .84

$$
\text { 5. } 25=84
$$


The Unit 731 Museum is a national museum with actual ruins of the unit 731 military base. The prisons, laboratories, and many feeding rooms this military troop once used were preserved as evidences to prove Japanese wartime atrocities. In this paper, the content in the bacteriological exhibit hall will be examined and elaborated because of its vast amount of evidences, explanatory information, and the models simulating the scene which Japanese doing experiments on living humans' bodies.

The bacteriological exhibit hall is divided into several sections, including "The Establishment and Demise of the Unit 731 Troop", "The Establishment of the Pingfang Special Military Zone ${ }^{14}$ ", "Bacterial Experiments", "Poison Gas Experiments", "Previous Soldiers and Workers' Testimonies and Models", "Shiro Ishii and bacterial warfare", "Field Experiments and Bacterial Warfare", "Field Experiment Simulation Scene". "Unit 731 Troop's Animal Breeding", and "Irrefutable Evidences". Important Explanatory information and one or two powerful evidences from one or several sections are illustrated in this paper.

\subsection{The Establishment and Demise of the Unit 731 Troop}

"In 1933, in order to further expand the aggression against China, Japan violated the Geneva Protocol 'the Protocol on the Prohibition of the Use of Asphyxiating, Toxic or Other Gas and Bacteriological Warfare Methods in War', and secretly established the Unit 731 troop. Claiming to be Kwantung Army Epidemic Prevention and Water Supply Department, Unit 731 Troop began the inhumane activities such as the horrible bacterial warfare, living humans bodies experiments. In August 1945, the Japanese military retreated under the powerful anti-Japanese army and the world anti-fascist forces. In order to preserve the secret of the Unit 731 troop, Japan issued a retreat in advance of the order, and on August 8 many of the facilities were blown up, data was destroyed and witnesses were killed...”.

\subsection{The Establishment of the PingFang Special Military Zone}

The PingFang Special Military Zone is 120 square kilo meters. The Military Zone was not only surrounded by wires, but also heavily guarded. The residents within this special military zone had a certificate of residence to prevent outsiders from visiting.

\subsection{Bacterial Experiments}

Walking into this section, a chart called "In Vivo Experiments Categories" (Figure 13) is hanged on the wall. The chart listed Unit 731's thirty-one ways of experimenting, including "intramuscular injection", "subcutaneous injection", "urine injection", "human and horse blood exchanged injection", "hypnosis", "connecting humans' esophagus and small intestine”, etc.

${ }^{14}$ PingFang Special Military Zone is a military area controlled by the Unit 731 troop. 


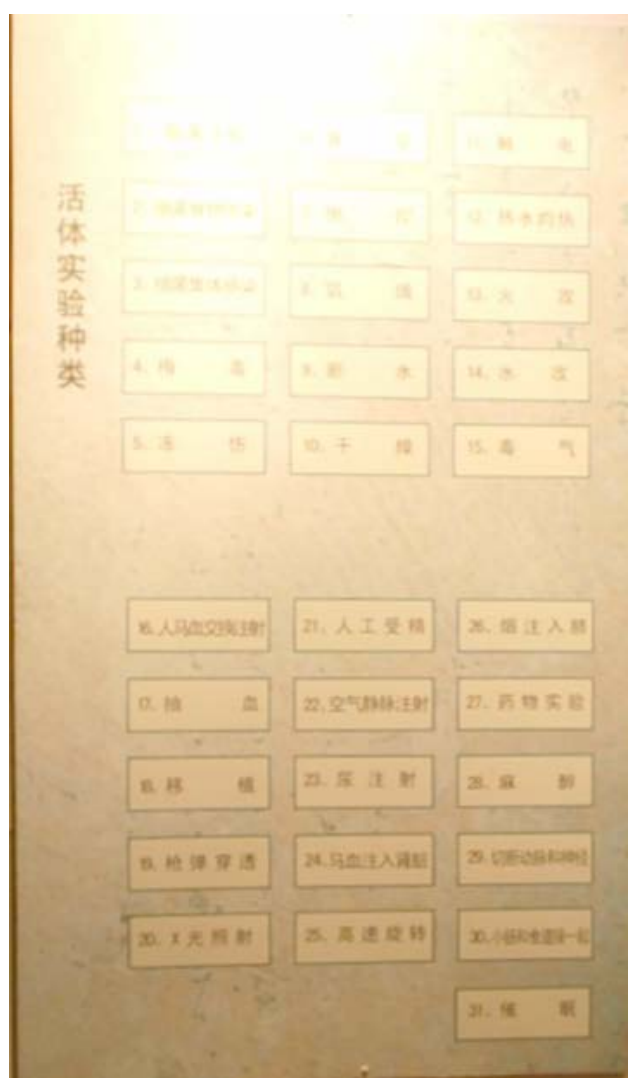

Figure 13. "Categories of In Vivo Experiments", Unit 731 Museum, 2010.

Figure 14 shows the scene of intramuscular injection, in which fifteen healthy people were divided into three groups, and 0.1 gram, 0.2 gram, 0.3 gram of bacteria were injected into these people to compare different bodies' reactions when attacked by these bacteria.

\subsection{Previous Soldiers and Workers' Testimonies and Models}

The core secret of the Unit 731 troop is the living human experiments and the bacterial warfare. Figure 15 and Figure 16 depict the wall which reveals the previous soldiers' confession, forced worker' testimonies and original archives. Many of the forced workers have passed away in the twenty-first century, so as early as the 90 s, the museum has notarized these documents. These reliable evidences are legally preserved, and can expose the Unit 731 crimes.

Figure 17 shows the vacuum experiment. The naked "maruta" ${ }^{15}$ " was caged in transparent sealed cabin; the air in the cabin would be gradually pumped away. When there is only half amount of air left, the person's eye will pop out like a goldfish, the blood vessels will pop out enormously. Despite the person's body is distorted, the internal organs, such as eyes, mouth, anus, and other body parts were squeezed out, the experiment is still going second by second, until the air pressure within the cabin became zero.

${ }^{15}$ Maruta: The insulting name the Unit 731 called to the people those are experimented. In Japanese maruta means "wooden log", which are the people that are experimented. 


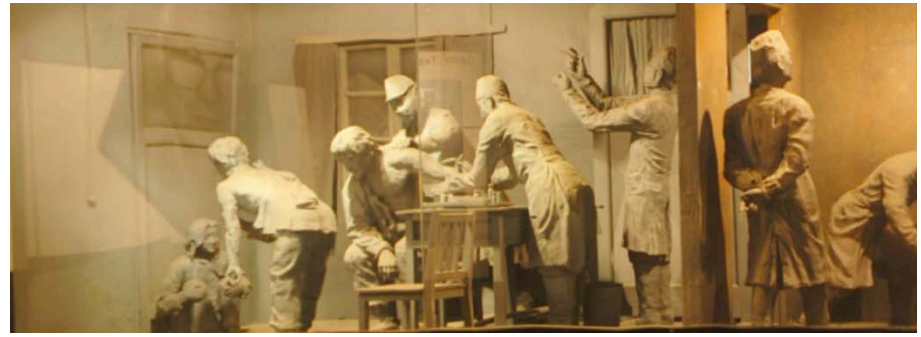

Figure 14. “Intramuscular injection” Unit 731 Museum, 2010.

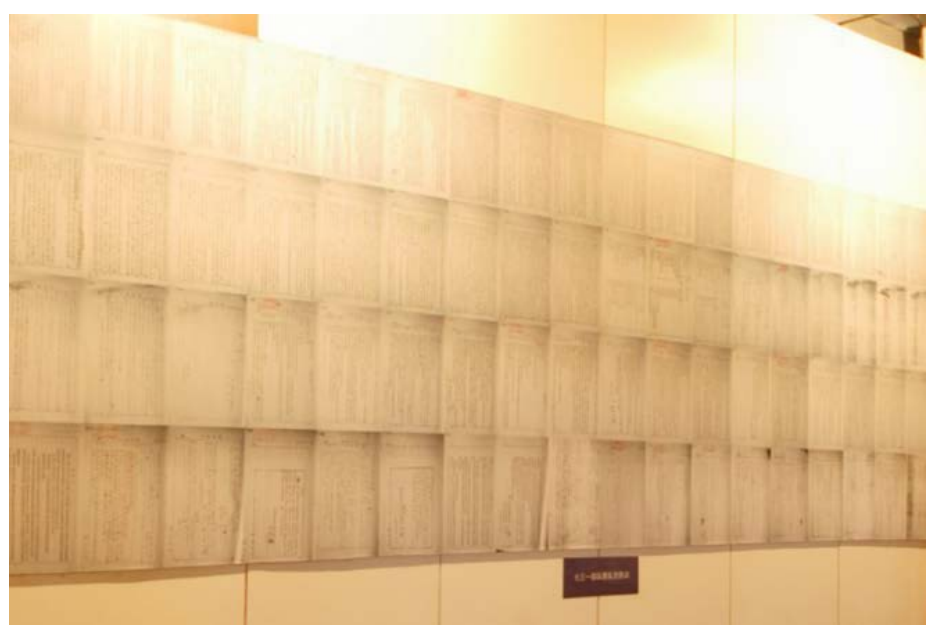

Figure 15. “Previous soldiers' Testimonies”, Unit 731 Museum, 2010.

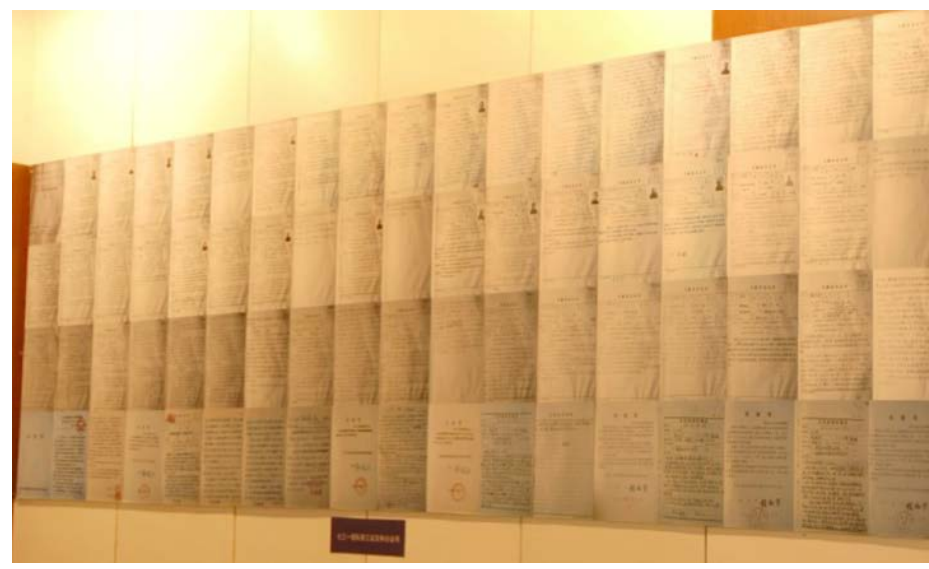

Figure 16. "Previous Workers' Testimonies”, Unit 731 Museum, 2010.

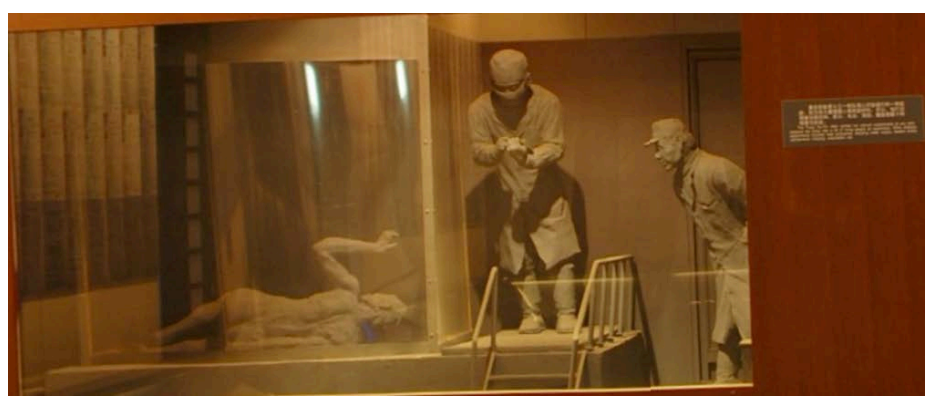

Figure 17. “The Vacuum Experiment”, Unit 731 Museum, 2010. 
Figure 18 shows the frost experiment, which is an important experiment category for the Unit 731 troop. The purpose of conducting the frost experiment is to help Japanese fighting in extremely cold environment. They tied people who are experimented in the field in winter to let them froze. These people skin and muscles will die and thus fall off. When their white bones were exposed, the people were carried back indoor to defrost and be further examined.

Figure 19 shows the scene in dissecting room. "The dissecting room in Unit 731 is the slaughter house to those people. Their hearts, lungs, or four limps were taken off and dissected".

\subsection{Shiro Ishii and Bacterial Warfare}

This exhibit room (Figure 20) is the office of Shiro Ishii. It was in here which Shiro Ishii and Masayuki Kitano had planned the bacterial warfare. Shiro Ishii

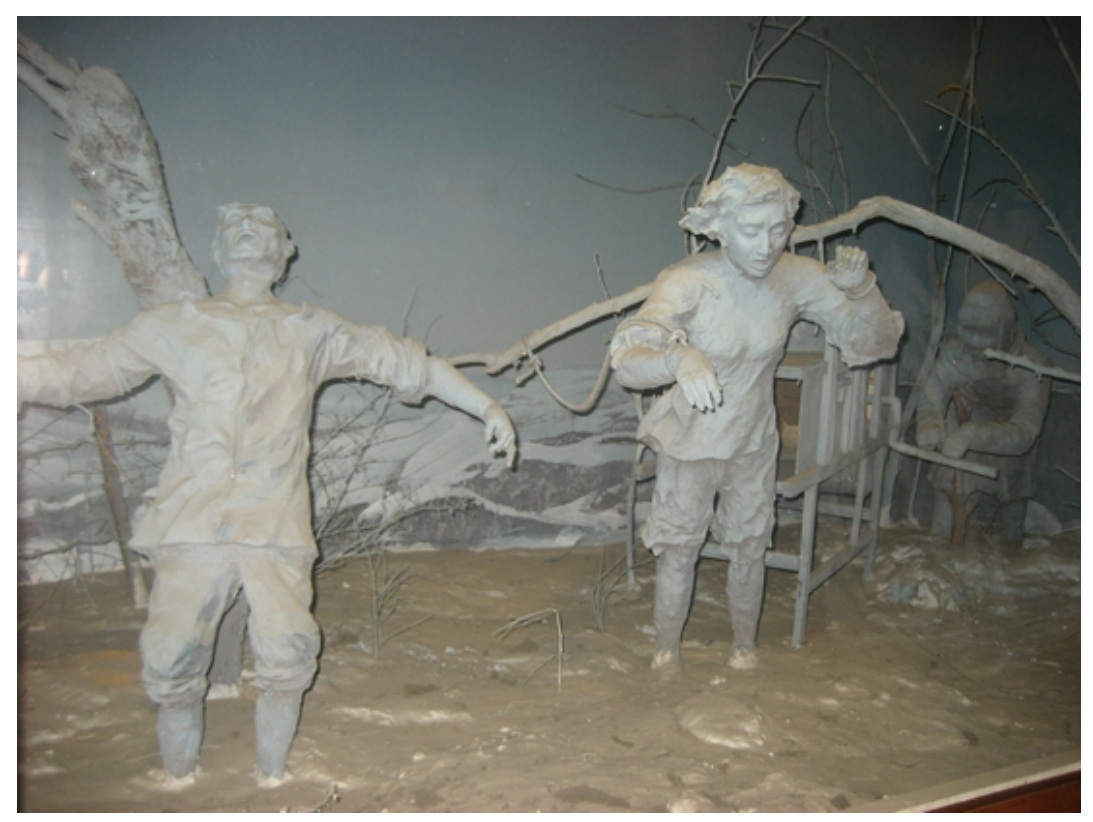

Figure 18. “The Frost Experiment”, Unit 731 Museum, 2010.

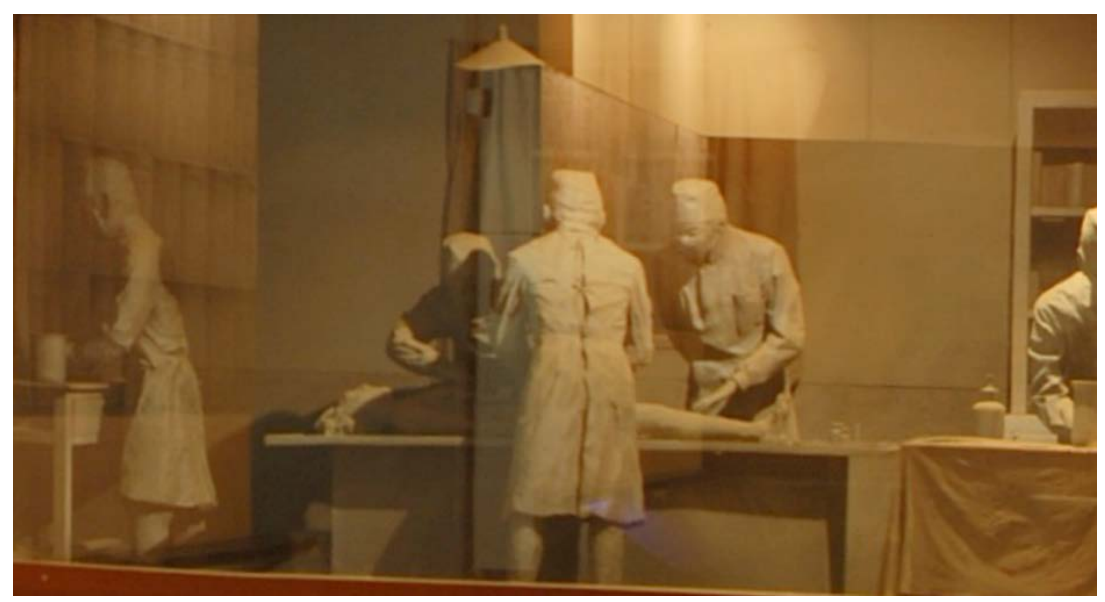

Figure 19. “The Dissection Room”, Unit 731 Museum, 2010. 


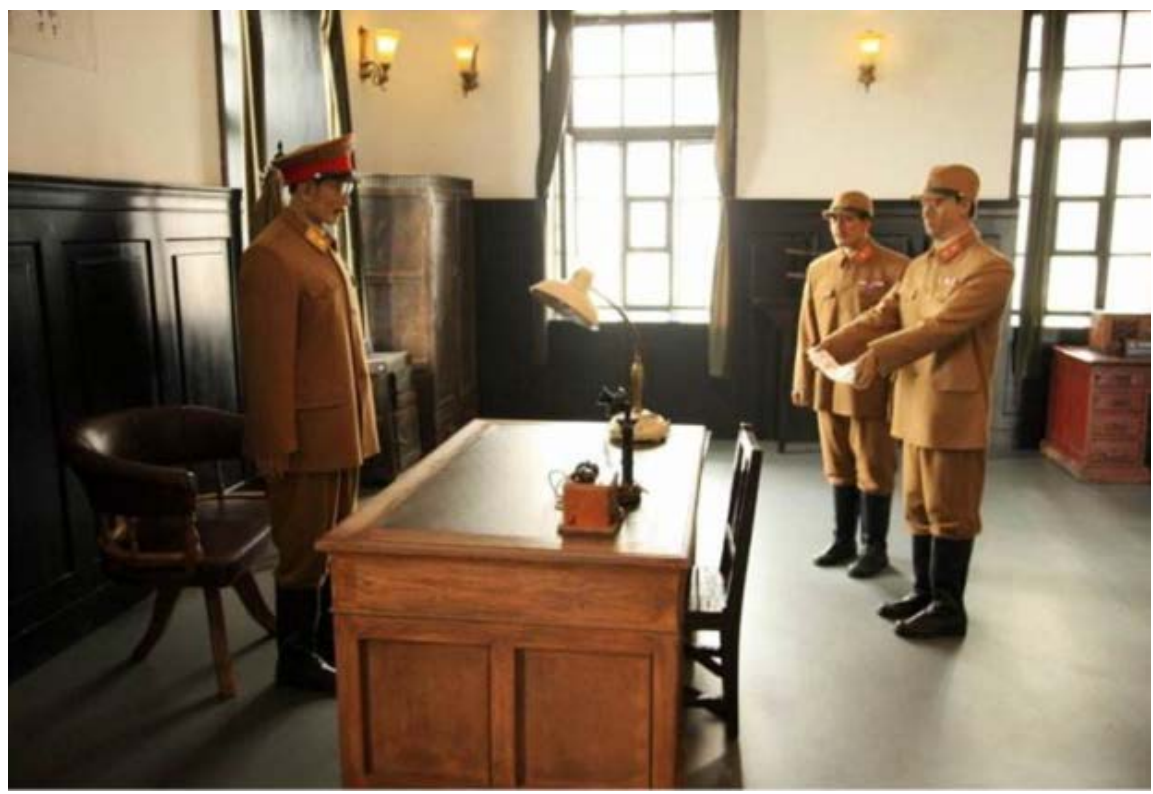

Figure 20. "Shiro Ishii's office”, Unit 731 Museum, 2010.

was born in 1892 in Chiyoda village in Japan; he was the main commander of Unit 731 troop. In order to have the bacterial bomb into the combat as soon as possible, he personally invented a pottery bacterial bomb; it has two advantages; the first one is its tolerance to heat; the second one is its fragility when the bomb is dropped to the ground. The bombs were loaded with fleas carrying plague. Thus it became very easy to spread plague around the people.

\subsection{Field Experiments and Bacterial Warfare and Field Experiment Simulation Scene}

In order to meet the demand of field combat, the Unit 731 troops built numerous field experimenting base in Jilin province, Hulun Buir Grassland, etc. In 1939, Japanese launched their first bacterial bomb in the NuoMenHan area, which is the border between China and Mongolia. In order to guarantee the success of the experiment, Unit 731 troop had established a death squad... After 1940, Unit 731 conducted field experiment in Southern part of China. Unit 731 troop's largest-scale bacterial warfare was in western part of ShanDong province of China; they use cholera bacteria in the battle, causing the death of two-hundred thousand people.

The bacterial warfare and human experiment require field experiment. Unit 731 had three important field experimenting base; the most famous one is $\mathrm{AnDa}$ experimenting base. As shown in Figure 21, the people who are experimented were dressed like Japanese soldiers. And they were tied to the wooden cross. The airplanes dropped the bomb Shiro invented, and many bacteria were spread among the people. In order to keep the experimented people living for further observation, Unit 731 covered their head and body with metal cap; only the four limps were exposed. 


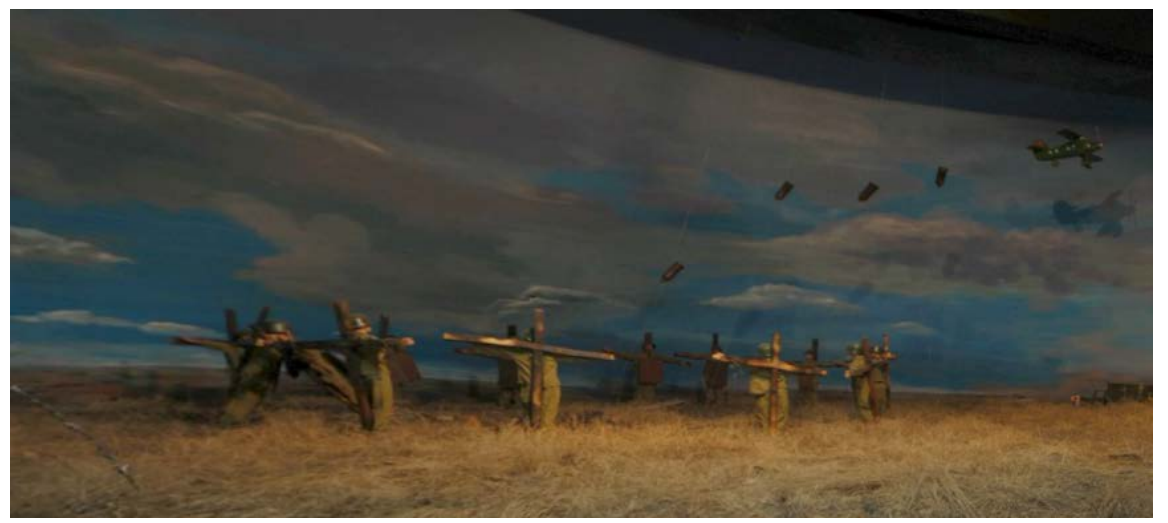

Figure 21. "Field Experiment in Anda”, Unit 731 Museum, 2010.

\subsection{Unit 731 Troop's Animal Breeding and Experimenting Tools}

This exhibit hall mainly consisted of experimenting tools, sanitizing equipment, and animal breeding tools. The dissecting hanger to hang human's organs during the dissecting process is included; each of these hangers had a three-digit sequence. One powerful prove for Unit 731 crime of conducting bacterial experiment is the injector found in 2000. As shown in Figure 22, there are also cages and mousetraps used by Unit 731 for animals breeding.

\subsection{Irrefutable Evidences}

Shown in Figures 22-24, the exhibit room is mostly composed of Chinese wartime newspaper, wartime image brochure, historical pictures albums, and identity certificate. Overall 491 pieces of articles were exhibited. This historical evidence was organized to fill the gap of historical record, truthfully conveying information, to fully demonstrate the section of irrefutable evidences of Japanese invasion.

\section{Analysis}

After comparing two specific Chinese and Japanese history textbooks and museums, it can be easily observed that there are great differences between these two nations' cultural interpretations of the war. Among all the materials related to the Sino-Japanese War, the chosen Chinese textbook straightforwardly points out Japanese territorial expansion, Japanese brutal atrocities, including the Nanjing Massacre, the tragedy in PanJiaYu, and the Unit 731 bacterial warfare, and emphasizes on the successful achievement CPC made in the war. However, the Japanese textbook describes Japan's domestic economic crisis as a reason of developing economic zone in China, Chinese Civil War between the CPC and Kuomintang, and Japanese diplomacy; unlike Chinese textbook's straightforward and obvious wordings accusing Japanese atrocities, Japanese textbook use relatively vague words when describing Japanese actions in China. And many wartime atrocities, such as the Nanjing Massacre and the comfort women, are not mentioned in the textbook. For the museums, the Hiroshima Peace Memorial Hall's Main Building is mostly composed of tragedies caused by the 


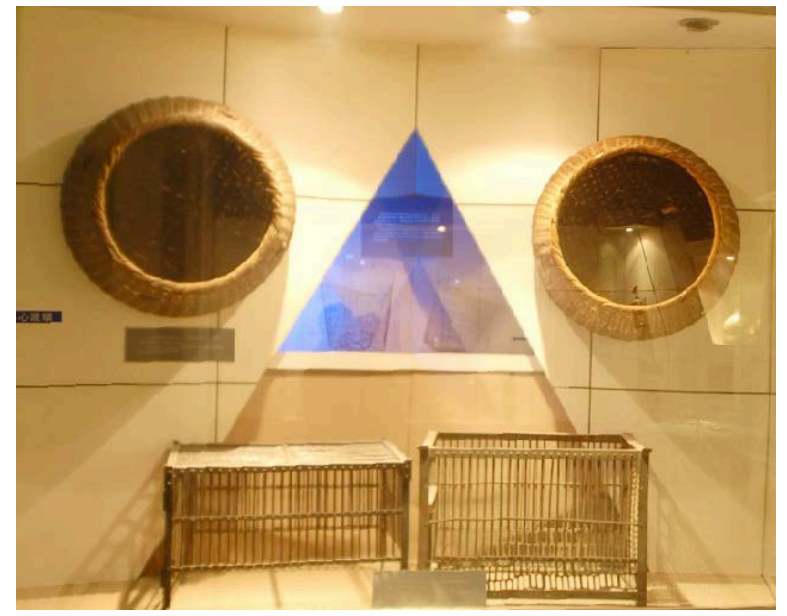

Figure 22. “Cages and Mousetraps”, Unit 731 Museum, 2010.

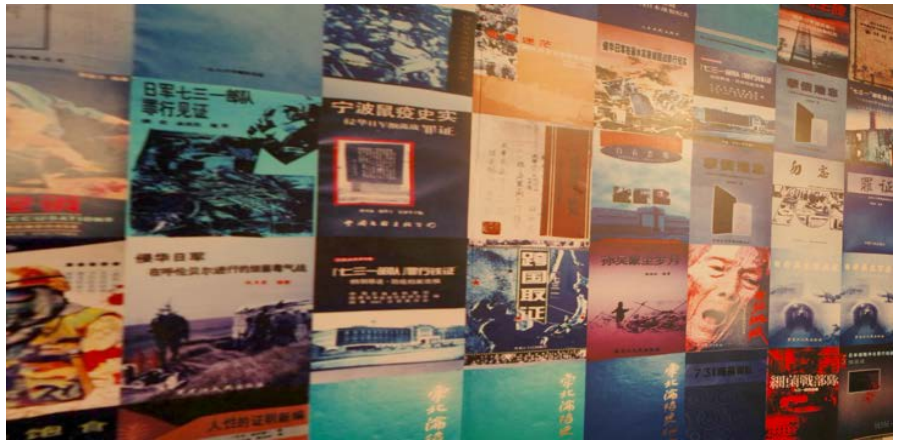

Figure 23. "Wartime brochure and picture albums", Unit 731 Museum, 2010.

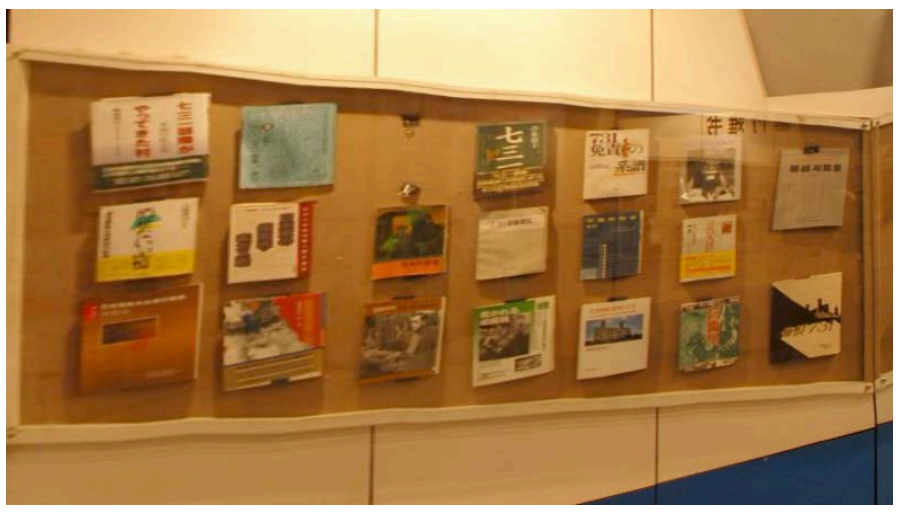

Figure 24. "Wartime Newspaper and Books", Unit 731 Museum, 2010.

A-bomb, survivors' emotional stories, and the huge mental and physical damage to the civilian population; a great variety of survivors' drawing and testimonies are included. The Unit 731 Museum's Bacteriological Exhibit Hall reveals the human experiments in the secluded Unit 731 military base; it gives introductory information, simulation models, and articles the Japanese used in the military base. Unlike the Hiroshima Peace Memorial Hall scarcely mentions United States' dropping the bomb, the Unit 731 Museum mentions the Japanese as the evil victimizers. 
In this part, the paper tends to analyze these distinctions, and consider social, historical, and political factors that might results these differences.

The leading social factor is the different war memories hold by Chinese and Japanese. Although all Chinese textbook, Unit 731 Museum, and Hiroshima Peace Memorial describe the severe damage on civilian population, their descriptions emphasize on different issues. The Chinese textbook and museum reflect Japanese atrocities, yet the Hiroshima Peace Memorial Hall reflects the damage caused by the nuclear bomb. The impressive and tragic part of the war is remembered differently for the Chinese and Japanese. Japanese atrocities caused tremendous physical and mental harm on Chinese people, and the nuclear bomb rendered two-hundred-twenty-five thousand casualties in Hiroshima and Nagasaki. In the words of John Dower, "Hiroshima and Nagasaki became icons of Japanese suffering-perverse national treasures, of a sort, capable of fixating Japanese memory of the war on what happened to Japan and simultaneously blotting out recollection of the Japanese victimization of others. Remembering Hiroshima and Nagasaki, that is, easily became a way of forgetting Nanjing, Bataan, the Burma-Siam railway, Manila, and the countless Japanese atrocities these and other place names signified to non-Japanese" (Dower, 2012). This psychology of Japanese people examined by Dower explains the emphasis on the catastrophe caused by the nuclear bomb. In the same way, the Chinese textbook and museum mainly portray the brutal action of the Japanese army because that is the most tragic and brutal experience; with the sense of hostility towards Japan, the victimizer of the atrocities, the nuclear bomb damage was not mentioned much in Chinese textbook.

On the other hand, Japanese sense of unity and the sense of national pride are pervasive throughout the current Japanese society. In order to demonstrate the strong extent of Japanese pride and unity, an example is provided below. Currently, Japan is facing low fertility rate and decreasing population, if the population continues to fall, there is a great possibility of economic depression and social stagnation. According to Sakanaka Hidenori, the former director of Tokyo Immigration Bureau, that the current number of foreign permanent residents is little over two million, which is 1.57 percent of the total population. Thus an immigration policy, which is to accept the influx of massive immigrants, has been proposed to solve Japan's domestic demographic and economic problem. The Japanese people are facing two options, whether to accept the vast amount of immigrants or deny this proposal. Sakanaka sorted the advantages and downplays of these two options. If the proposal is denied, in which the immigrant number is still limited, several consequences must be carried by Japan, including a natural decline of population, greater responsibility must be carried by native Japanese, and turning Japanese society into a compact one. If the proposal is accepted, which means there will be over twenty million immigrants for fifty years, several consequences also needed to be faced by Japan, including building infrastructure to accommodate the immigrants, turning Japan into a multiethnic so- 
ciety, and foreign cultures will be blended into Japanese culture (Taylor \& McNeill, 2007). Economy or culture? That is the choice the Japanese was facing to make. According to Professor James McClain's lecture, in the public poll, most Japanese chose to reject the proposal. The Japanese would rather take on heavy burden and having the society become compact, but not blending their unique Japanese culture. This public poll indicates the great sense of cultural pride and social unity of the Japanese people. And a reason why Japanese textbook and museum ignore the information of invasion and atrocities; this enormous pride of being a Japanese and the united feeling being within the Japanese society may be difficult for Japanese to face the dark history they have done in the war.

Another important historical factor that affects Japanese textbook's evading information relating to Japanese wartime atrocities and Hiroshima Peace Memorial Hall's not accusing the victimizer is the postwar U.S. Japan relation. After the two nuclear bombs were dropped in Hiroshima and Nagasaki, the emperor announced the unconditional surrender in 1945. From 1945 to 1951, the United States had occupied Japan until the peace treaty was signed. Douglas Macarthur, the Supreme Commander of the Allied Power, was dispatched to govern Japan temporarily. According to professor McClain's lecture, Macarthur wanted Japan to be revitalized and develop democracy and capitalism, which are system shared by the United States. Instead of executing the emperor, Macarthur did not punish the emperor in order to avoid the resentment the Japanese would hold against United States. His actions tend to rally the Japanese to support the US. Furthermore, Macarthur is responsible of rewriting the Constitution of Japan, issued in November 3, 1946. In 1946, Macarthur has gathered prominent Western scholars to draw up the Constitution of Japan, which was later announce by Emperor Hirohito. The constitution pledged that "We, the Japanese people, acting through our duly elected representatives in the National Diet, determined that we shall secure for ourselves and our posterity the fruits of peaceful cooperation with all nations and the blessings of liberty throughout this land, and resolved that never again shall we be visited with the horrors of war through the action of government, do proclaim that sovereign power resides with the people and do firmly establish this Constitution. Government is a sacred trust of the people, the authority for which is derived from the people, the powers of which are exercised by the representatives of the people, and the benefits of which are enjoyed by the people. This is a universal principle of mankind upon which this Constitution is founded". The great sense of democracy, the reliance on democratic government, and a deep relation with United States had been developed by Macarthur. This relation and the sense of dominance Macarthur showed in postwar Japan may explains the Hiroshima Peace Memorial Hall's not accusing US's dropping the nuclear bomb. On the other hand, not only did not Macarthur execute the emperor, many Japanese wartime atrocities were not seriously accounted and A-class criminals were released after the trail. Kishi Nobusuke was the General Secretary of Ministry of Commerce of the Manchukuo Gov- 
ernment in 1936, and the Cabinet Minister of Industry in 1941. Later becoming the head of the Munitions Ministry, Kishi was responsible of bringing thousands of Chinese and Korean workers as slaves to work in Japan's factories and mines for military production (Schaller, 1995). Overall, 670,000 Koreans and 41,862 Chinese were brought into Japan to work as slave labor under terrible conditions (Dower, 1993). According to Kishi's actions during the war, he was judged as a A-class criminal, those who committed crimes against peace, on the International Military Tribunal of the Fast East. However, he was released later under Macarthur's occupational ruling in 1948. "With China racked by a civil war and Europe politically divided and economically prostrate, the Truman administration viewed Japan, like Germany, as a power vacuum into which Soviet influence might flow. Soviet control of German and Japanese industrial potential, men such as... Navy (later Defense) Secretary James Forrestal believed, would tilt the global balance in Moscow's favor. In simplest terms, Forrestal put it, real security against communism required the 'restoration of commerce, trade and business' worldwide. This meant putting 'Japan, Germany and other affiliates of the Axis back to work'” (Schaller, 1995). Under this historical context, Kishi was not only released, but also became the Prime Minister in 1957. Elaborating Kishi Nobusuke's case as an example, many disputes over war crimes and criminals remained unsolved under the postwar and pre-Cold War historical context; the crimes were not seriously accounted and criminals later became powerful nation leader; and this may be a factor resulting Japanese textbook's evading information relating to Japanese wartime atrocities.

Political factors also play a huge role of explaining the distinct interpretations. The long-standing conservative thinking, starting in the later period of the Meiji Restoration, prevailed in Japan. According to Professor James McClain's lecture, the complex political situation prior to the war gave rise to the conservatives. During the Taishō modernity (1905-1930s) and the beginning of Shōwa backlash (1930s-1945), increasing tensions existed between the liberal and cosmopolitan thinking of the rising middle class and the socialist and anarchist thinking of the radical left. This consistent tension rendered the conservatives' gaining support. Under the threat of Western Imperialism and the disdain the conservatives held against Western ideas, the strong tide of conservatives made the decision to go to war. The conservative government emphasized on glorification of Japan and not cooperating with Western nations. Until this day, the conservative thinking remained dominant in Japan as Shinzo Abe is reelected as Prime Minister in 2015. It offers explanation for Japanese textbooks and museums not mentioning Japan's wartime atrocities: the dominant conservative thinking that drove Japan to war is still dominant presently.

The different interpretations rendered government legitimacy in both China and Japan. "During the 1950s-1970s, China avoided history disputes with Japan to focus on geostrategic interests. Only from the early 1980 s did domestic political incentives motivate Beijing to attack Japanese historical memory and promote assertive nationalism through patriotic history propaganda, which radica- 
lized Chinese popular views about Japan" (He, 2007). The later inspired historical memory serves national interest, and this memory, according to Yinan He, "constitutes an integral part of ideological foundation for national identity and nationalism though often distorting historical facts, myths present a picture of the shared past that can evoke the deepest emotional resonance from the populace. Elites use these highly symbolic myths to justify national security policy or address domestic political concerns" (He, 2007). It can be seen in the Chinese textbook that the Communist party was praised as the paramount success to the Sino-Japanese War, and important military general of the CPC and important battles the communist had fought are elaborated in the textbook. While the Kuomintang is scarcely mentioned. Portraying the Communist Party as the hero liberating and uniting China evoked definite nationalism and support to the current Communist government. This kind of postwar propaganda reinforced ordinary Chinese people heavy reliance, admiration and trust to the Chinese Communist Party.

The means that used by both Chinese and Japanese government to gain political benefit is victimization injected in textbooks and museums. The Chinese textbook reveals the brutal Nanjing Massacre, tragedy in PanJiaYu, and the Unit 731 bacterial warfare; the Unit 731 Museum offers evidences and depicts the inhumane human experiment and the enormous torture the bacterial warfare has brought to Chinese civilian population. These tragedies constantly appear in Chinese textbook and museums; and the Chinese people are presented as absolute victims. This way of victimization units the citizens against the Japanese invasion and creates a strong sense of nationalism. As one of the most important museums in Japan, the Hiroshima Peace Memorial Hall vividly exhibits the "living hell" the Japanese people had gone through. Many emotional stories, powerful damaged articles, and survivors' testimonies are exhibited. The intentional victimization creates the picture that the Japanese has also suffered severely through the war to the international world; thus induce less blame on Japan for its engaging in the war.

\section{Conclusion}

Admittedly, the paper compares only two examples of the textbooks and two examples of the museum. However, looking at the characteristics of the differences, some factors which resulted in these distinctions can be sorted out and examined. As Michael Walzer said in his work Just and Unjust Wars, "For as long as men and women have talked about war, they have talked about it in terms of right and wrong", people tend to judge war with definite right and wrong to ingratiate certain purposes, which leads to relatively extreme and biased result (Walzer, 2006). This paper tries to inspire readers to perceive the distinctions between interpretations of the war from a different perspective, and to realize the historical influence, nationally dominant political view that is largely injected into history textbook and the popular citizens' memories with strong personal emotions that fulfilled war museums. 


\section{References}

Dower, J. (1993). War without Mercy: Race \& Power in the Pacific War. New York, NY: Pantheon.

Dower, J. (2012). Ways of Forgetting, Ways of Remembering: Japan in the Modern World. New York, NY: The New Press.

He, Y. (2007). Remembering and Forgetting the War: Elite Mythmaking, Mass Reaction, and Sino-Japanese Relations, 1950-2006. History and Memory, 19, 43-74.

Jeans, R. (2005). Victims or Victimizers? Museums, Textbooks, and the War Debate in Contemporary Japan. The Journal of Military History, 69, 149-195.

https://doi.org/10.1353/jmh.2005.0025

Kazuhiko, K. (2017). Modern World History Revised Edition A315. Yamagawa: Yamagawa Press.

People's Education Publishing House and Course Material Institute History Research and Development Center (2007). Historical Compulsory 1/Ordinary High School Curriculum Standard Experimental Textbook. Beijing: People’s Education Publishing House.

Schaller, M. (1995). America's Favorite War Criminal: Kishi Nobusuke and the Transformation of U.S.-Japan Relations. Japan Policy Research Institute.

Shibuichi, D. (2008). Japan's History Textbook Controversy: Social Movements and Governments in East Asia, 1982-2006. Electronic Journal of Contemporary Japanese Studies.

Taylor, A., \& McNeill, D. (2007). The Future of Japan's Immigration Policy: A Battle Diary Introduction by Andrew Taylor and David McNeill. The Asia-Pacific Journal, 5.

Walzer, M. (2006). Just and Unjust Wars: A Moral Argument with Historical Illustrations. New York, NY: Basic Books. 